\title{
EU pension policy and financialisation: purpose without power?
}

\section{Waltraud Schelkle}

This article asks whether the EU's pension policy promotes and achieves financialisation of old age security. Financialisation in this context means financial market integration that, in conjunction with pension reforms in member states, creates a market-based mode of governance for old age security. After an overview of how significant private pension funds have become in the EU, the article takes a most-likely case study of financialisation, the Pan-European Pension Product (PEPP), to see how successful the EU's pension policy proved to be in establishing the PEPP. The findings suggest that EU policymaking in pensions tries to instrumentalise financial market integration for pension provision but this does not necessarily lead to financialisation of old age security. Market integration is a multi-faceted process of creating, emulating and correcting markets that obstructs a single-minded policy thrust like financialisation.

Keywords: capital markets union, EU, financialisation, pension policy, political economy

\section{Financialisation and EU pension policy}

An early meaning of financialisation portrayed it as an accumulation regime that replaces industrial capitalism and the national models which had evolved with it (van der Zwan 2014: 101-2). The imperative of capitalist activity becomes to privilege financial over real investment by maximising the financially measurable and tradeable shareholder value of corporations. An element of this is that governments are expected 'to promote an "equity culture" in the belief that it will enhance the ability of its own nationals to compete internationally' (Dore 2008: 1098). While the focus is on nation-states, in particular the US, European integration could also be portrayed as a handmaiden of financialisation (Engelen 2003: 1359; Pochet 2003: 50). It can transform national accumulation regimes by opening up 
new business opportunities for transnational financial firms (Hassel et al. 2019): after all, market integration happens by harmonising national legislation and regulation that ensures the freedom of capital and financial services. The latest idea of a Capital Markets Union (CMU) is a project with a financialising potential.

The proposition of financialisation is both objectionable and tempting when it comes to old age security, which is the theme of this special issue. Pensions are a sensitive area for the EU, because old age security is a prerogative of national welfare states which can be closed off for competition, to be Europeanised only at the margins (Schelkle 2013). Institutions, eg national tax treatment of pension savings and their stakeholders, middle class voters or organised labour market parties, have often proved formidable hurdles to European integration of pension provisions. But there are also strong incentives to make financial market integration and an 'equity culture' serve old age security. If private finance would offer attractive pension products, it could help to solve two problems that the EU Commission has long emphasised: first, it might reduce governments' expensive obligation to secure living standards in old age and, second, it might diversify longevity risks and thereby stabilise the returns on pension savings across member states. This makes financialising initiatives an attractive proposition to the Commission, member state executives, and sometimes even social partners.

But how sustained and ultimately successful are attempts at promoting financialisation in European integration? The literature has noted that financialisation is often a state-sponsored process (Boyer 2000; Krippner 2011: 2; Natali 2018: 459). Financial sector interests are likely to support pension financialisation through market integration. However, and this is key to my analysis and argument, market integration combines market making with regulation. Most of the financialisation literature suggests that regulation will not stop financialisation from progressing regardless (Berry 2016; Engelen 2003). The theoretical background to this is that Classical Political Economy sees big business (here: cross-border 
finance) and politics as prone to collusion in self-serving ways. However, state actors, including supranational technocrats, may pursue their own agenda when promoting market integration and stabilisation, here: financialised governance of old age security. Keynesian political economy has explained this role of the state in a long and inclusive list of scholarly work, explicitly so in Weir and Skocpol (1985) and Hall (1989). State-sponsored market integration typically entails a good deal of social regulation of markets to satisfy concerns of various constituencies but also to protect the public purse against exposure (Schelkle 2012; Tuytens 2018). This agenda can even be supported by parts of the financial sector, for their own reasons: integrative measures can create unwanted competition and certain market failures pose existential threats to some but not others. This heterogeneity of financial interests, combined with policymakers' sensibilities for market failure, render financialisation of pensions a much less straightforward proposition than the financialisation literature has it. Market integration can mean at least three different things that do not serve financial interests uniformly: first, the creation of cross-border markets invariably leads to some domestic business losing out; second, the emulation of market principles like competition can undermine business opportunities created by state-guaranteed property rights; and, third, market correction may eliminate exploitative or discriminatory practices on which business once thrived. The next section outlines in more detail how the European Commission pursues all three of these elements with respect to cross-border markets for pensions and follows this up in the case study of a Pan European Pension Product (PEPP). This unpacking of what market integration entails helps us to understand how European integration may, but does not have to, lead to financialisation of old age security. It is an empirical question. My working hypothesis is that EU-sponsored financial market integration for pensions does not lead to pension financialisation in the sense that the accumulation of pensions rights becomes financialised (Boyer 2000) or a risk-return calculus and individual responsibility will become priorities (Langley 2008: 70) relative to social policy and insurance concerns; even some 
financial actors may express such concerns, possibly for self-serving, anti-competitive reasons.

The next section describes the theoretical approach for analysing financialisation in the Keynesian tradition of political economy and relates it to the relevant literature. It is followed by a brief look at the evidence for a trend towards financialisation in the sense of pension privatisation in EU member states. Next, the article takes up a most likely case study of financialisation, the creation of an EU-standardised personal pension plan, which was a financial sector initiative that the Commission turned into an attempt at positive integration of pension markets. The conclusions discuss whether the EU is a purposeful agent of pension financialisation and which the most important limitations are on its power to act in this way.

\section{The concept of pension financialisation}

The literature on accumulation and growth regimes (Aglietta 2000: 156-8; Engelen 2003) considered whether the ageing of rich countries is the structural force behind a self-fulfilling dynamic of rising demand for financial assets and rising asset prices, generating financial cycles and establishing the central bank as 'the linchpin of the whole financial structure' (Aglietta 2000: 156). The notion of 'pension fund capitalism' (Clark 2000) studied the investment behaviour of private pension funds given that they may exercise an increasing role in corporate governance of non-financial firms. Financial sociologists and IPE scholars of the 'everyday life of global finance' (Langley 2008: ch.4) considered whether an increasing share of privately funded pensions and a variable rate of return (Defined Contribution, DC) - instead of pensions that come with a promised benefit (Defined Benefit, DB) -- would turn citizens from insurance-seeking savers into yield-craving investors.

In this article, I will argue that financial expansion and cross-border integration is necessary but not sufficient for the diagnosis of financialisation. I propose a theoretical framework that can make sense of the already existing comparative evidence that shows 
symptoms of pension financialisation in very different welfare states, while others fail to show such symptoms despite the rise of finance; hence, time-honoured regime typologies will not do. ${ }^{1}$ This framework is based in the Keynesian tradition of political economy, which is opposed to historical determinism and interested in policy choices, in contrast to the original financialisation literature in a classical (Marxist) tradition (van der Zwan 2014: 101-2). Keynesian political economy has as its central tenet that financial markets are the gatekeepers to investment and employment in capitalist economies. Notwithstanding this pivotal role of financial markets, the Keynesian tradition also maintains that financial markets are prone to failures and, occasionally, to systemic failure, as in the Great Depression. Finance needs the visible hand of government to stabilise markets although the necessity does not guarantee that the hand is always willing and able to help. This insight made Keynes, the economist, also a political economist, for instance in his newspaper articles on 'the economic consequences of Mr Churchill' in 1925. Ideas, enshrined in existing institutions, can have a more or less retarding effect on policy change but they also make state action more than the result of societal pressures (Widmaier 2016: 10-11). This allows 'the role of the state enlightened by Keynesian reason [to be] that of a great "reconciler" of individual and collective interests', to use Mann's (2016: 124) ironic but insightful characterisation. Keynesian political economists, from Weir and Skocpol (1985) to Eichengreen (2007), have shown that even conservative administrations adopted ever more responsibilities and business-friendly governments refrained from endorsing laissez faire, especially when faced with disastrous market failure.

We can take these insights further by asking what role state actors like the EU Commission and business play in the rise of finance. In contrast to the Keynesian optimism that state intervention and activism tend to be desirable and feasible, the financialisation literature has pointed out early on that state-sponsorship was implicated in bringing about a problematic dominance of financial-commercial over socio-economic considerations (Krippner 2011). In a similar vein, this article disentangles the meaning of European market 
integration to find out how actors interested in integration promote financialisation but also why they may fail to do so (Grahl and Teague 2005: 1008-10).

There is, first, the creation of (cross-border) markets for pension savings and longevity insurance where there were none before. Financial regulation of pension provision, such as harmonised standards for prudential supervision, is one main instrument for creating cross-border markets as providers can then use the licence in the home state as a passport to markets in other member states. A parallel EU standard, in addition to national regimes, can also create a new transnational market. But market opportunities for some often come at the cost of others, for instance pitch banks against insurers with regulatory compromises limiting the opportunities for both.

Secondly, the emulation of market principles in occupational and public schemes serves to foster integration of very different systems. The (ex)portability of pension rights can be seen as the emulation of market principles in statutory pensions, facilitating mobility of workers competing for jobs in other member states. The emphasis on fiscal sustainability in an ageing society can also be seen as a market emulating thrust since it tries to instil a hard budget constraint on public finances, analogous to constraints faced by commercial providers. This emulation of market principles can contribute to financialisation in the third sense of the individualisation of risks. But it can also undermine business opportunities in member states, notably where demand for private pension plans is propped up by tax-subsidies, inhibiting the expansion of other pension plans.

Finally, in line with established evidence on market liberalisation (Vogel 1996), regulation tends to be introduced over time to correct failing markets, typically in the wake of some scandal or investigative media reporting. In fact, we should expect tight regulation especially in markets for social services because member states already treat this as a sphere where market correction is required. Discrimination due to asymmetric information, on grounds of nationality and gender, is a relevant example for market failure in insurance 
generally and pensions specifically. While market correction can help insurance markets for longevity to function and provide established firms a competitive advantage, it can also rein them in if they thrived mainly on excessive fees and risk-shifting to ignorant customers.

Two questions arise: first, what exactly are the drivers of financialisation? Van der Zwan (2014: 106) notes that the forces behind financialisation as an accumulation regime are often left in the abstract. One of the few exceptions, Krippner's historical-sociological study of the US, identified state officials dealing with policy dilemmas (Krippner 2011: 22), a finding that is perfectly in line with Keynesian political economy. This article examines whether the EU Commission was indeed the key driver, and considers its relationship to organised financial interests. Second, how contentious were apparent changes in the governance of old age security? While market creation and emulation is always popular with business, market correction should be contested by business although not in principle since regulation is an element of competition (Vogel 1996). The Keynesian vantage point leads me to expect that political concerns about market failure that cause political embarrassment and impose adverse distributional outcomes on core constituencies can easily derail a onedimensional drive towards pension financialisation, however attractive the latter may appear at first.

\section{Financialisation and national pension systems}

Member states' pension systems developed under a complex set of influences of which EU pension policy is but one. Engelen (2003: 1357-8) claimed that private funding of old age security could come to rival public provisions. The most recent available OECD data on the significance of private pensions among 22 EU member states shows that Denmark and the Netherlands have accumulated private pension funds worth double their GDP, followed in some distance by the UK, Sweden and Finland (OECD 2017: Tables 8.1 and 8.4). With the exception of the UK, one would not expect these political economies to be the paragons of 
Anglo-American pension financialisation. Member states also vary considerably in terms of coverage.

The level of public and private gross payouts ${ }^{2}$ suggests that only the Netherlands, Sweden and the UK qualify as having financialised pension systems. Private funds contribute a sizeable share to old age security only in these three countries, i.e. between more than half (Netherlands) and more than a third (Sweden) of all benefit-expenditure (OECD 2017: Tables 7.3 and 7.4). The fact that these three countries represent very different welfare state configurations supports to some extent the claim of financialisation scholars that it can be a common, transnational trend.

The relative immaturity of private funds could be responsible for the low number of 'financialised' countries, especially in Central and Eastern European countries. A better way may therefore be to look at relative growth of public and private benefits. The most recent data for 2000-2013, during which new member states had time to build up private funds, shows that out of the 22 EU members for which the OECD (2017) provides data, six experienced financialisation (Austria, the Czech Republic, Germany, the Netherlands, the Slovak Republic, and Sweden) in the sense that private pension payouts rose faster than public pensions. Only Germany reduced spending on public pensions and built up, from a very low level, a private layer. But another six member states show the opposite, increasing public spending while private pension benefit-expenditure fell (e.g. Denmark, from $2.4 \%$ of GDP in 2000 to $1.0 \%$ in 2013). It should be noted that a small drop in payouts looks large, given low levels of private pensions in most countries (eg a decline in France from $0.3 \%$ of GDP in 2000 to $0.2 \%$ in 2013 amounts to a decrease by one third). ${ }^{3}$ The OECD (2017: 144) notes that, on average, private pension benefits are stable since around 2000, after they increased from $1.0 \%$ of GDP in 1990 to $1.5 \%$. This includes occupational and personal pensions. 


\section{A cross-border market for personal pensions ${ }^{4}$}

This section looks at an initiative by European banks and the European Commission to lend personal pensions a helping hand. The focus on these actors stacks the cards against my working hypothesis: the financialisation literature suggests that they should be the most single-minded promoters of financialisation. My conceptual framework outlined above suggested that market integration does not mean a single direction of travel towards financialisation. So when would market integration in practice mean financialisation? The case study does not speak to financialisation as shareholder value maximisation in corporate governance. But financialisation in the other two meanings is potentially observable. A financialised regime of pension accumulation would manifest itself in a) markets for PanEuropean personal pensions being created through regulatory competition among national regimes; b) market principles being emulated by fiscally prudent support for annuities markets; and c) markets being corrected only through low prudential standards. Financialisation as socialisation of individual investors would be indicated by d) market creation that consists of a shift from DB to DC pensions, e) market emulation through unlimited plan options, and f) market correction only through low standards of consumer protection. The guiding principle of the assessment is that rule-based integration contributes to financialised pension accumulation if it replaces a public policy logic with a commercial logic (eg competition rather than wide equitable risk-pooling, life-long income through annuities markets rather than pay-as-you-go pensions) and projects individuals as active investors calculating risk and return (of a DC pension) who can make choices over EU-wide offers.

The plan to create a standardised EU-wide personal pension scheme, the PEPP started out, in the mid-2000s, as an initiative by the European Financial Services Round Table (EFR), which is an organisation of currently 23 CEOs of the biggest banks and insurers in Europe. The EFR asked for an EU regime parallel to the then 25 national legal regimes that 
governed personal pensions. A parallel regime requires the Commission to abandon the usual harmonisation approach. The EFR initially did not get 'much applause from Brussels' as Nijssen (2006), the former global head of pensions at ING Group, put it in an online journal of the pension industry. He summarises the EFR's motivation straightforwardly: 'The EFR rightly states that arranging pan-European pensions by harmonising the national legislation of 25 EU countries is virtually a mission impossible. So why not take a short cut by having an EU-wide '26th regime' framework with only a limited number of basic principles that are acceptable to all member states?'

About a year later, on 8 May 2007, the (Ecofin) Council of Economic and Finance ministers ended with conclusions on 'Ageing and financial markets' that invited the EFR to specify their proposal. This encouraging response was not necessarily expected since the significance of private pensions in member states is negligible for many, as we have seen above. The EFR report in June reframed the issue of an EU-wide pension scheme and sounded as if written by the ministers themselves: responding to the 'demographic challenge' meant that entitlements of tomorrow's pensioners will be reduced and a 'pensions gap' would arise that personal (and occupational) pensions could fill (EFR 2007: 4). This pensions gap rationale would later be echoed by the Commission when it asked EIOPA ${ }^{5}$ to advise on the PEPP (EIOPA 2014: 4-5). The original EFR proposal for an expedited legislative process for Single Market legislation on pensions was only the last of six reasons for why a PEPP is needed. We can see in this the mirror image of the well-known state-sponsorship of financialisation, ie organised financial interests adapting to and sponsoring a public agenda.

The EFR report analysed the differences in personal pension legislation in five different countries (Czech Republic, France, Germany, Italy and the Netherlands) to identify obstacles to an EU-wide scheme. At several points, the authors deny that different tax treatments would constitute a major impediment. Tax harmonisation is anathema to most member states and any attempt in this direction would have killed the proposal. ${ }^{6}$ On the 
subject of tax subsidies to old-age provisions, the report resorts to the principle of nondiscrimination, ie 'any Member State may limit the tax deductibility or tax incentives given to contributions to a Pan-European pension plan, as long as these limitations do not constitute unequal treatment in comparison with other pension plans.' (EFR 2007: 35) It also proposed a minimum of old age security, in the form of nominal value protection: ' $[\mathrm{t}]$ he provider has to offer at least an option in which the value of the plan at the retirement is not less than all the contributions paid minus expenses (including the cost of the additional risks covered).' (EFR 2007: 18, 33) The deduction of expenses would make this a weak form of nominal guarantee, and EIOPA as well as the European Parliament later wanted to cap these expenses or have the principal guaranteed before the deduction of fees (European Parliament 2018: A63). Such guarantees create a default risk for insurers because they create nominally fixed obligations while the corresponding assets have a variable nominal value. The EFR report thus conceded the need for consumer protection which comes at a risk for the pension provider. It is an ambiguous (protective and risky) move in terms of financialisation.

Fast forward to 2011-12, when the Commission launched a White Paper on 'safe, sustainable and adequate pensions'. This was obviously against the background of massively increased public debt in the wake of the financial crisis but also considerable risks to pension funds, which had lost up to $25 \%$ of their value at the bottom of the stock market crash (Laboul 2011). At a public event organised by EIOPA, a Commission official gave four reasons for the initiative on behalf of three DGs (EIOPA 2014: 4): first, care for the old age security of migrants, the number of which had increased from $2.1 \%$ of the labour force in 2005 to $3.1 \%$ in 2012; second, adapt regulation in line with 'the general shift towards individual responsibility for securing retirement income (DB to DC)'; third, address various market failures so that governance and risk management are dealt with adequately in all member states; and fourth, compensate low or declining replacement rates of public and occupational schemes (the 'pensions gap'). 
A central claim of the Commission was that these multiple objectives would be served by market integration. Given the background of a financial crisis, this claim was hardly selfevident. Furthermore, it was argued that, for pensions, the best strategy for integration would be to create a so-called $2^{\text {nd }}$ regime product: in other words, to set out common standards for a scheme with a European 'kitemark' that would be acceptable in all member states and fully transferable across borders. This was in line with the original EFR proposal of a parallel regime and strongly supported by the financial services sector and by EIOPA, the financial supervisor for pension funds. The latter argued that 'a $2^{\text {nd }}$ regime product instead of a Directive harmonising European standards is the best solution to keep the costs low, by avoiding legal uncertainty and gold-plating by Member States.' (EIOPA 2016: 67) The Commission may not have been enthusiastic at first, yet the PEPP follows the EU approach in occupational pensions. IORPs standardised an organisational form, ie cross-border providers of occupational pensions. Both IORPs and PEPPs are designed to complete the Single Market for longevity insurance, with the capacity to pool risks across member states even if all citizens were immobile. One can see in this approach an attempt at introducing a financialised regime of pension accumulation in that it puts competitive pressure on national regulation, a concern that was later expressed by PensionsEurope $(2018: 9,11){ }^{7}$

EIOPA's vision for the PEPP stressed the importance of counteracting market inefficiencies and failure on the supply side: scale economies and competition had to be increased so as to raise financial returns; products made trustworthy; transparency and information requirements raised (EIOPA 2014: 6). Given cognitive biases on the consumer side, EIOPA advocated a 'caveat venditor' (sellers beware) principle, as had been suggested for auto-enrolment to occupational pensions in the UK (EIOPA 2016: 69-70). If something goes wrong, pension providers have to prove that they fulfilled their obligations rather than the client-savers having to prove that they were not made aware of the risks. Clearly, EIOPA did not see individuals as investors who could be left to their own devices. 
Insurers were not enamoured by this approach. Insurance Europe (2016) argued that the proposals did not take the specificity of pension products sufficiently into account; the PEPP was more like an ordinary savings product than a pension. It criticised provisions that would allow consumers to switch frequently and the proposed information requirements which were the same as for investment products, covering the rate of return, but not tax treatment, the payout phase, and the biometric risks. Last but not least, the organised insurers criticised that the EU proposal did not insist on an option that would deliver a life-long income, notably annuities (Insurance Europe 2016: 5). In other words, the insurance association insisted that a pensions product is different from individual savings accounts insofar it provides insurance for longevity and possibly survivors. By neglecting these differences, the Commission proposal took the path of pension financialisation.

But the lobby group of European insurers also objected to the prescription of a default option that guarantees the capital paid in and wanted instead an unlimited number of investment options; nor did the insurers association support any cap on costs and charges (Insurance Europe 2016: 6, 7). In other words, Insurance Europe would have liked a proposal that would strengthen the insurance industry's competitive advantage as Europe's major personal pensions and annuities provider vis-à-vis other financial institutions, while giving insurers maximum commercial flexibility. This was in contrast to PensionsEurope (2018: 14), which supported limited investment options, taking their long-term impact on 'environmental, social and governance factors' into account instead of problematising them as a commercial constraint.

The final proposal for a PEPP was published by the Commission in June 2017. The European Parliament discussed hundreds of amendments; and the Council gave a mandate for negotiation with the Parliament on 19 June $2018 .{ }^{8}$ Senior officials in the Commission stress that this was supported by three Directorates, for Social Affairs, the Internal Market and Competition. The emphasis shifted to the contribution that such a pension product could 
make to the CMU. The Commission had been emboldened by a Council resolution of 28 June 2016, five days after the Brexit referendum, to pursue CMU, originally a pet project of the UK government. Taking this cue from the Council, the PEPP became a vehicle for facilitating long-term investment in the depressed EU economy. It would presumably do so by reducing the need for maturity transformation through matching long-term savings, by reducing their costs through standardisation, and by helping 'them pool contributions from different national markets' (Commission 2017a: 3). This vision was directly opposed by PensionsEurope (2018: 7): 'PEPPs cannot be considered as pure investment products, as they are connected with social policy in general and pension policy in particular, both prerogatives of the Member States.' The Council position paper for the final negotiations would reflect this prerogative by requesting that PEPPs be authorised nationally rather than supranationally (Council 2018: para's 14, 56).

The proposal includes a mandatory safe option, with nominal value protection, among a maximum of five investment options. The Commission's version is not inflation-indexed. As the European Federation of Investors and Financial Services Users notes in its contribution to the consultation: $2 \%$ inflation over 40 years wipes out $55 \%$ of the value of pension savings (Better Finance 2017). The European Parliament (2018: A130) requires a safe option to be inflation-indexed and include fees. Even so, a 'safe' default option arguably rules out a pure DC scheme.

The Commission proposal contains detailed information requirements and, in Article 48 , caps on the costs of switching providers to $1.5 \%$ of the balance to be switched (Commission 2017a: 8, 13). This figure is much higher than any explicit switching fees prevailing in member states (OECD 2017: 161) and the European Parliament has sought to lower it to $0.5 \%$ (EP 2018: A152). The proposal enumerates all the types of providers it wants to encourage to take up PEPP, insurers being only one of them (Commission 2017a: 3). It stresses that self-employed and even unemployed citizens can thus save for their 
retirement. The Commission adopted the approach of the regulator, EIOPA, with its financial-supervisory attention to market failure. The proposals are oriented to correcting asymmetric information and misperception on the consumer side, and lack of competition and transparency of terms and conditions on the supply side. ${ }^{9}$

However, the proposal contains very little on decumulation. It does not prescribe an option that provides for lifelong income and leaves the regulation of payout options to member states' national legislation (Articles 51-2). To prescribe more would have entered the contested area of social policy and tax harmonisation which the Commission shied away from. Annuities markets are under-developed in most member states because they depend on underpinning from government. ${ }^{10}$ Governments must share in the longevity risk because private insurers have the same problems as pension policymakers in estimating the continuous rise in life expectancy. But if private annuity providers get it wrong, as they have in the past, they may go bust. Governments can support annuities markets by, for instance, issuing more long-term bonds. But these are costly in public debt management terms as investors demand higher yields (Stewart 2007: 7). Moreover, governments are reluctant to share longevity risks with private insurers as they are already overexposed to these risks through their public pension systems. Last but not least, governments need to make annuities attractive, eg through tax incentives, or mandatory, as there is otherwise an adverse selection problem: predominantly socio-economic groups with a long life expectancy choose annuities (Stewart 2007: 9). But enforcing annuities in this way would expose governments to the critique that they force people with health conditions or shorter life expectancy, typically correlated with lower income, into unfavourable insurance contracts that benefit disproportionately the worried well. One of the most controversial requests of the European Parliament (2018: A34, Art.52(2)) is therefore that the 'basic option' should contain a mandatory fixed annuity of $35 \%$. This element of pension financialisation - providing a life- 
long income through financial markets - is at cross-purposes with the risk appetite of governments. This prevents the development of more complete markets for old age security.

One grave limitation of attempts to create a cross-border pension product is the lack of provision for a safety net for failing pension providers. A pension provider's default is arguably a remote possibility, but a severe stock market crash that diminishes the value of assets, when a large share of obligations consist of the safe (nominally guaranteed) investment option have made this a quantifiable probability. Article 49 concerns only the protection of savers in the case of financial losses short of the PEPP provider's default. Chapter IX on supervision does not say anything about default of a large cross-border pension provider, except that EIOPA would have some conciliation role if national supervisors cannot agree (Article 56).

The PEPP proposal shares this blind spot with the CMU initiative that assumes stock market investors can bear their losses, even though the experience of the financial crisis in 2007-9 suggests otherwise. Regulations had to be suspended at the height of the crisis so that pension providers did not become technically insolvent: the crash of asset prices pushed their reserve holdings below statutory levels and made returns plummet (OECD 2015).

This omission is rather striking. From the perspective of Keynesian Political Economy, whereby state actors have some autonomy in undertaking welfare-enhancing market regulation, the best explanation is ideational (Hall 1989; Tuytens 2018). The Commission remains attached to a pre-crisis paradigm of financial regulation. The proposal asks for investment of pension savings according to the relatively low standard of the 'prudent person rule' (Article 33). The responsibility of supervising compliance with these stipulations lies with national supervisory authorities and the prudent person rule makes it very hard to avoid a race to the bottom as it can mean different things in different jurisdictions (Haverland 2007). The European Parliament has not challenged this low standard of prudential supervision, although it has stipulated considerably more protection for 
'PEPP savers', notably that the conditions in the 'basic' option for 'the accumulation phase [..] shall be no less favourable than applicable national rules' (European Parliament 2018: Art.40). Although it is hard to see how to operationalise this amendment, it is a clear signal against a permissive interpretation of prudential principles.

We can thus conclude this section on the PEPP by noting that the proposal has changed its thrust quite a bit over the lifetime of its gestation. The following overview (Table 1) summarises the findings.

[Table 1 about here]

The summary shows elements of financialisation in the design of the PEPP but overall more counter-evidence. First of all, rules that would have allowed for a relatively financialised accumulation regime (parallel transnational regime, low standard of prudent person rule) were undermined by rules for consumer protection that cater to individuals as risk-averse savers (no pure DC but an option with a weak nominal guarantee, limited options, caveat venditor principle); the amendments of the European Parliament will make this protective thrust even more pronounced. Furthermore, even within the provisions for a financialised accumulation regime, market emulation did not work in favour of market creation because support for annuities markets was not to be had in fiscally prudent terms. The trilogue negotiations are likely to accommodate the Council position by introducing more national prerogatives because PEPPs are part of social law; in return, the European Parliament is likely to introduce more stringent consumer protection. My erstwhile conclusion is that the financial industry, especially the initiating banks, will not show much interest in offering the PEPP.

\section{Conclusion: purpose without power?}

The evidence provided above suggests that there is no sign of a pervasive shift to private 
pension funding in EU member states. The rise of pension finance in the 1990s has levelled off in 2000, pension assets and coverage rates in most EU member states do not suggest relevance and salience. Public pensions have also continued to rise (OECD 2017: 143-4). But the Council responded encouragingly to an initiative by organised interests in European banking for an EU-wide personal pension product which, after initial reluctance, three important Directorates in the Commission dutifully supported. The article traced the evolution of this proposal to its fruition in 2017 and the onset of the legislative process up to September 2018.

Even this most likely case for pension financialisation does not find it. The relevant literature interprets limited evidence as a matter of time: the accumulation of private pension claims and the shift to DC schemes will make financialisation ever more prevalent (Engelen 2003: 1369-70: Langley 2008: 87; Natali 2018: 459-60). My theoretical framework, applied to an admittedly small case study, leads me to a principled objection to such projections. It can be formulated in contrast to Posner and Véron (2010) who see 'power without purpose' in the EU's approach to financial regulation. I see a purpose, financial market integration, which is so multi-faceted, however, that it does not translate into straightforward financialisation. And the power of the EU is rather limited because, contrary to what the financialisation literature says, finance as a 'power resource' is divided, here: between banks, insurers and pension funds. The pushback tends to come from national state actors using this division.

The EU has a pension policy that reaches all three layers of old age security (public, occupational, personal) through rules-driven market integration (Anderson 2015: ch.4; Schelkle 2013). But they are subject to differentiated regulation, as Keynesian political economy would lead one to expect. Such differentiation could be observed in our case study. The initial emphasis of an EU-wide personal pension plan was on market creation, through a parallel regime that promised a short-cut around regulatory harmonisation. As preparations 
progressed, the mandatory reports by the pension regulator EIOPA added a heavy dose of market correction that made the entire policy proposal much less attractive for banks and insurers. The European Parliament and, interestingly, PensionsEurope pushes further in that direction. Finally, the real or perceived budget constraints of member states, an element of market emulation that EU fiscal surveillance keenly pursues, ruled out the extension of tax subsidies to the new Pan-European plan as well as public support for attractive features like a market-based provision of life-long income.

Even if market integration would point in one direction, the lack of power is another obstacle to financialisation as a policy agenda. The main stakeholders of a financialised EU pension policy look for market opportunities, first and foremost, rather than for a stabilising market infrastructure. The CEOs sitting around the EFR clearly saw an untapped source of business for their members and lost interest as ever more market correction made it into the proposal. The critical response of the European insurance association indicated that they noticed the opening up of competition in a market segment where their members dominated. But even though the organised insurers raised valid points against pension financialisation in the original proposal of the banking lobby, their own intervention came across as self-serving and opportunistic. The lack of legitimate supporting interests limits the power of the EU to instrumentalise financial markets for social policy purposes. The Council, supported by PensionsEurope (2018), requested more control over this process exactly because social policy is a national competence which in turn constrains the Commission in its available instruments. The EU's exclusively regulatory power is ultimately limited power because the Commission cannot engage in fiscal sponsorship of pension financialisation through tax incentives or safety nets.

Financial interests can still exert influence, of course. The mixed evidence shown in the summary above could be read in this way. Naczyk (2013: 445) reviews a number of studies, which show that private insurers have historically always lobbied in favour of 
containing public pensions. While the evidence from the OECD (2017) suggests that they have not been very effective in this respect, the insurance elements of the PEPP indicate that they may be heard in other respects. But the financial industry did not speak with one voice. This observation expands on the argument of Naczyk (2013): he finds that 'capital' is not of one mind when it comes to pension privatisation, employers can be ambivalent while financial firms support it. The PEPP case study suggests that financial firms disagree once we get to the details of pension privatisation and the compromises can neutralise some of their influence.

More research is needed on how finance actually exerts influence, in comparison with other collective actors (Natali 2018). Even the most painstaking research on the US (Krippner 2011: ch.3; Langley 2008: ch.4) is about the unintended consequence of policy changes that empowered finance, not about how finance used its power in bringing about financialising policy changes. If financial market integration is to be harnessed for old age security, the EU may have to cultivate institutionally a network of diverse stakeholders (European Parliament 2018: A147). But again, the representation of diverse interests would work against financialisation becoming the sole logic governing pension funding. Neither purpose nor power make the EU a force for pension financialisation.

\section{Biographical note}

Waltraud Schelkle is Associate Professor in Political Economy at the London School of Economics (LSE)

\section{Correspondence}

European Institute, LSE

Houghton Street

London WC 2 2AE

UK 


\section{Funding}

This research was funded by the German Federal Ministry of Education and Research, BMBF (Bundesministerium für Bildung und Forschung). Grant number: 01UF1508.

\section{Notes}

1. In addition to the contributions in this issue, Belfrage (2008: 290) finds that Swedish households have not turned from passive savers to active investors; Mabbett (2012) shows that savers have to be 'nudged' to join private pension schemes in Anglo-America; and Natali (2018: 459-60) notes varying degrees of financialisation in Italy, the Netherlands and the UK.

2. Gross means before taxes on benefits and without tax subsidies for pension savings because neither is comparable across countries (OECD 2017: 144).

3. The other four member states for 'de-financialisation' were Belgium, Finland, Italy, and the UK (OECD 2017: Tables 7.3 and 7.4).

4. I am grateful for background interviews with Per Eckefeldt and Luigi Giamboni (DG Ecfin), on 4 July 2017. They are not responsible for any misunderstandings and the following is strictly my interpretation.

5. EIOPA is the European Insurance and Occupational Pensions Authority, a regulatory agency created for the Single Market in financial services.

6. Similarly, labour and social law have seriously obstructed the proliferation of pan-European occupational pension funds, IORPs (Guardiancich 2011: 24-5).

7. PensionsEurope represents national associations of occupational and personal funded pension providers.

8. Rust (2018). The Council had to overcome divisions regarding the question whether IORPs should be allowed to offer PEPPs; the compromise was that those who can offer personal pensions under national law should also be allowed to offer PEPPs. The Economic and Monetary Affairs Committee of the European Parliament finalised its position in September 2018 and the trilogue negotiations were to start around the time of writing. 
9. However, biometric risks, such as survivor benefits, can be covered by a PEPP which favours insurance providers (Commission 2017a: 13, Art.42).

10. The only OECD countries that have developed annuities markets are Australia, Canada, Switzerland, the US and the UK (Stewart 2007: 3n). The UK market collapsed after 2015 when compulsory annuitisation of tax-subsidised pension savings was abolished.

\section{References}

Aglietta, M. (2000) 'Shareholder value and corporate governance: some tricky questions', Economy and Society 29(1), 146-159.

Anderson, K. M. (2015) Social policy in the European Union, Basingstoke: Palgrave MacMillan.

Belfrage, C. (2008) 'Towards 'universal financialisation' in Sweden?', Contemporary Politics 14(3), 277-296.

Berry, C. (2016) 'Austerity, ageing and the financialisation of pensions policy in the UK', British Politics 11(1), 2-25.

Better Finance (2017) Feedback from: Better Finance. URL:

https://ec.europa.eu/info/law/better-regulation/initiatives/com-2017343/feedback/F6960 en.

Boyer, R. (2000) 'Is a finance-led growth regime a viable alternative to Fordism? A preliminary analysis', Economy and Society 29(1), 111-145.

Clark, G. L. (2000) Pension fund capitalism, New York: Oxford University Press.

Commission (2012) White Paper. An Agenda for Adequate, Safe and Sustainable Pensions, (16.2.2012), COM(2012) 2055 final, Brussels: European Commission.

Commission (2014) Proposal for a Directive of the European Parliament and the Council on the activities and supervision of institutions for occupational retirement provision (recast). (27.3.2014), COM(2014) 2167 final, Brussels: European Commission. 
Commission (2017a) Proposal for a Regulation of the European Parliament and of the Council on a pan-European Personal Pension Product (PEPP). (29.6.2017) COM(2017) 343 final, Brussels: European Commission.

Commission (2017b) Commission recommendation of 29.6.2017 on the tax treatment of personal pension products, including the pan-European Personal Pension Product. C(2017) 4393 final, Brussels: European Commission.

Council (2018) Regulation on Pan-European Pension Product-Mandate for negotiations with the European Parliament. 9975/18. 16 June 2018. Brussels: Council of the European Union.

DG Justice (2011) European Commission gives guidance to Europe's insurance industry to ensure non-discrimination between women and men in insurance premiums. Press Release IP/11/1581. Brussels: European Commission.

Dore, R. (2008) 'Financialization of the global economy', Industrial and Corporate Change 17(6), 1097-1112.

EFR (2007) Pan-European Pension Plans. From Concept to Action. (June) Brussels: European Financial Services Roundtable.

EFR (2012) EFRP Position Paper. 2011/0296 (4 May), Brussels: European Federation for Retirement Provision. Retrieved from http://www.pensionseurope.eu/system/files/2012\%20\%20EFRP\%20Position\%20Paper\%20\%20MiFID\%20II MiFIR\%20-\%20final\%20-\%202012-05-04.pdf

Eichengreen, B. J. (2007) The European economy since 1945: coordinated capitalism and beyond, Princeton: Princeton University Press.

EIOPA (2014) Towards an EU single market for personal pensions. An EIOPA Preliminary Report to COM. EIOPA_BoS_14/029. Frankfurt a.M.: European Insurance and Occupational Pensions Authority. 
EIOPA (2016) EIOPA's advice on the development of an EU Single Market for personal pension products (PPP). EIOPA-16/457. Frankfurt a.M.: European Insurance and Occupational Pensions Authority.

Engelen, E. (2003) 'The logic of funding European pension restructuring and the dangers of financialisation', Environment and Planning A 35(8), 1357-1372.

European Parliament (2018) Report on the proposal for a regulation of the European Parliament and of the Council on a Pan-European Personal Pension Product (PEPP), A8-0278/2018. 6 September. Brussels: Committee on Economic and Monetary Afffairs.

Grahl, J. and Teague, P. (2005) 'Problems of financial integration in the EU', Journal of European Public Policy 12(6), 1005-1021.

Guardiancich, I. (2011) 'Pan-European pension funds: Current situation and future prospects', International Social Security Review 64(1), 15-36.

Guardiancich, I. and Natali, D. (2012) 'The cross-border portability of supplementary pensions: Lessons from the European Union', Global Social Policy 12(3), 300-315.

Hall, P. A. (1989) The Political power of economic ideas: Keynesianism across nations, Princeton, N.J.: Princeton University Press.

Hassel, A., Naczyk, M. and Wiß, T. (2019) 'The political economy of pension financialisation: public policy response to the crisis', Journal of European Public Policy [= SI paper, details to be added by editors/producer].

Haverland, M. (2007) 'When the welfare state meets the regulatory state: EU occupational pension policy', Journal of European Public Policy 14(6), 886-904.

Insurance Europe (2016) Insurance Europe's comments on Pan-European Personal Pension Products. PERS-.SAV-16-026. Brussels: Insurance Europe aisb1

Krippner, G. R. (2011) Capitalizing on crisis: the political origins of the rise of finance, Cambridge, MA and London, England: Harvard University Press. 
Laboul, A. (2011) 'Pension fund assets climb back to pre-crisis levels but full recovery still uncertain', Pension Markets in Focus (July), issue 8, OECD.

Langley, P. (2008) The everyday life of global finance: saving and borrowing in AngloAmerica, Oxford, New York: Oxford University Press.

Mabbett, D. (2009) 'Supplementary pensions between social policy and social regulation', West European Politics 32(4), 774-791.

Mabbett, D. (2012) 'The Ghost in the Machine: Pension Risks and Regulatory Responses in the United States and the United Kingdom', Politics \& Society 40(1), 107-129.

Mabbett, D. (2014) 'Polanyi in Brussels or Luxembourg? Social rights and market regulation in European insurance', Regulation \& Governance 8(2), 186-202.

Mann, G. (2016) ‘Keynes resurrected? Saving civilization, again and again', Dialogues in Human Geography 6(2), 119-134.

Naczyk, M. (2013) 'Agents of privatization? Business groups and the rise of pension funds in Continental Europe', Socio-Economic Review 11(3), 441-469.

Natali, D. (2018) 'Occupational pensions in Europe: Trojan horse of financialization?', Social Policy \& Administration 52(2), 449-462.

Nijssen, J. (2006) 'Push to break down barriers', IPE magazine (May).

OECD (2015) 'Can pension funds and life insurance companies keep their promises?', OECD Business and Finance Outlook 2015 (pp. 111-147). Paris: OECD Publishing.

OECD (2017) Pensions at a Glance 2017, Paris: OECD Publishing.

PensionsEurope (2018) Position paper on the pan-European Personal Pension Product (PEPP). 26 January 2018. www.pensionsEurope.eu

Pochet, P. (2003) 'Pensions: The European Debate', in G. L. Clark and N. Whiteside (Eds.), Pension Security in the 21st Century, Oxford and New York: Oxford University Press, pp. 44-63. 
Posner, E. and Veron, N. (2010) 'The EU and financial regulation: power without purpose?', Journal of European Public Policy 17(3), 400-415.

Rust, S. (2018) EU council reaches compromise proposal on PEPP. IPE news, 20 June 2018.

Schelkle, W. (2012) 'A crisis of what? Mortgage credit markets and the social policy of promoting homeownership in the United States and in Europe', Politics \& Society 40(1), 59-80.

Schelkle, W. (2013) 'The political economy of regulating longevity insurance in the EU', in U. Neergard, E. Szyszczak, J. W. van de Gronden, and M. Krajewski (Eds.), The Role of Social Services of General Interest in EU Law, The Hague: TMC Asser Press, pp. 433-457.

Stewart, F. (2007) 'Policy Issues for Developing Annuities Markets', OECD Working Paper on Insurance and Private Pensions, Paris: OECD.

Tuytens, P. (2018) The Political Economy of Private Pension Provision. Unpublished PhD thesis. London: LSE.

van der Zwan, N. (2014) 'Making sense of financialization', Socio-Economic Review 12(1), 99-129.

Vogel, S. (1996) Freer Markets, More Rules: Regulatory Reform in Advanced Industrial Societies, Ithaca: Cornell University Press.

Weir, M. and Skocpol, T. (1985) 'State structures and the possibilities for 'Keynesian' responses to the Great Depression in Sweden, Britain and the United States', in P. B. Evans, D. Rueschemeyer and T. Skocpol (Eds.), Bringing the state back in, Cambridge: Cambridge University Press, 107-163.

Widmaier, W. W. (2016) Economic Ideas in Political Time: The Rise and Fall of Economic Orders from the Progressive Era to the Global Financial Crisis, Cambridge: Cambridge University Press. 
Table 1. Findings of the PEPP case study

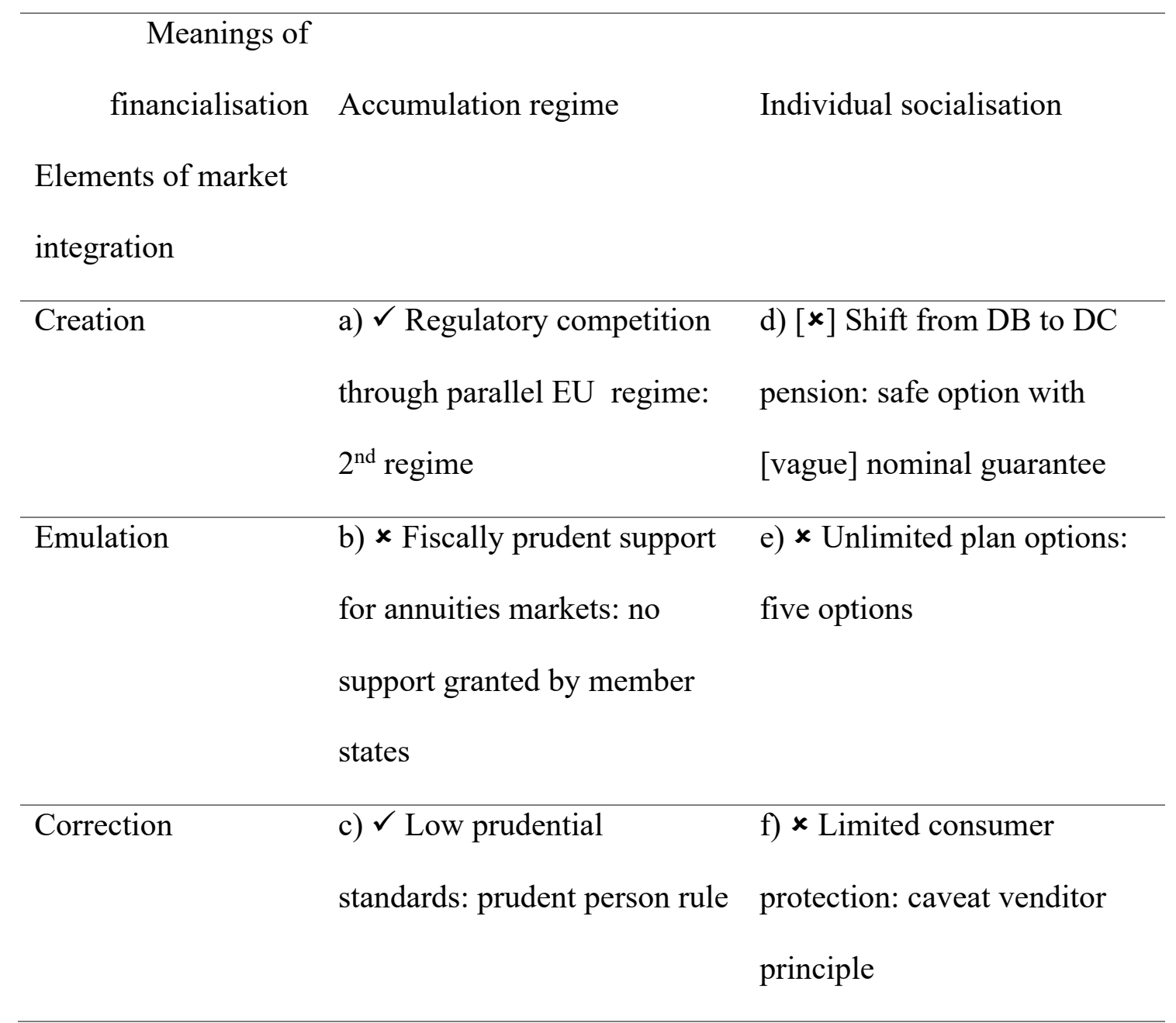

Note: $\checkmark$ stands for a positive finding of financialisation, $\boldsymbol{x}$ for a negative finding 